\title{
Thermal Devolatilization Kinetics of Dry Distiller's Grains with Solubles (DDGS)
}

\author{
Carmen Branca $^{1, *}$ and Colomba Di Blasi ${ }^{2}$ \\ 1 Istituto di Sviluppo e Tecnologie per l'Energia e la Mobilità Sostenibili (STEMS), C.N.R., P.le V. Tecchio, \\ 80125 Napoli, Italy \\ 2 Dipartimento di Ingegneria Chimica, dei Materiali e della Produzione Industriale, Università degli Studi di \\ Napoli “Federico II", P.le V. Tecchio, 80125 Napoli, Italy; diblasi@unina.it \\ * Correspondence: carmen.branca@stems.cnr.it; Tel.: +39-081-7682232
}

check for updates

Citation: Branca, C.; Di Blasi, C. Thermal Devolatilization Kinetics of Dry Distiller's Grains with Solubles (DDGS). Processes 2021, 9, 1907. https://doi.org/10.3390/pr9111907

Academic Editor: Elio Santacesaria

Received: 23 September 2021

Accepted: 23 October 2021

Published: 26 October 2021

Publisher's Note: MDPI stays neutral with regard to jurisdictional claims in published maps and institutional affiliations.

Copyright: (c) 2021 by the authors. Licensee MDPI, Basel, Switzerland. This article is an open access article distributed under the terms and conditions of the Creative Commons Attribution (CC BY) license (https:// creativecommons.org/licenses/by/ $4.0 /)$.

\begin{abstract}
Dynamic thermogravimetric analysis is applied to investigate the thermal devolatilization of dry distiller's grain with solubles (DDGS), the major by-product of bioethanol plants. Compared with lignocellulosic biomass, the DDGS devolatilization occurs over a much wider temperature range and with slower rates. This reveals complex dynamics attributable to a peculiar chemical composition comprising, in addition to lignocellulose, proteins, starch and other minor components. The evolution of lumped volatile product classes is well described by a five-step reaction mechanism. The numerical solution of the ordinary differential equations together with a minimization of the objective function leads to activation energies invariant with the heating rate. The estimated values of $89,120,158,102$ and $113 \mathrm{~kJ} / \mathrm{mol}$ are, on average, higher than those obtained under oxidative environments but still lower than those typically estimated for wood.
\end{abstract}

Keywords: DDGS; pyrolysis; devolatilization; TGA; kinetics

\section{Introduction}

The dry distiller's grains with solubles (DDGS), the major by-product of the grainbased bioethanol industry, is a protein- and lignin-rich biomass [1]. Apart from directly fermentable sugars, bioethanol is currently produced from cereals (e.g., corn, wheat and barley) by means of the so-called dry milling process. Briefly, the whole grain is milled and liquefied, then enzymatic hydrolysis is applied to transform the starch into sugars, which are fermented by yeasts to produce ethanol and $\mathrm{CO}_{2}$, while protein-derived nitrogen and lignin-derived aromatics are enriched in the solid residue [2-4]. In summary, DDGS contains both lignocellulosic (cellulose, hemicellulose and lignin) and non-lignocellulosic (mainly proteins and amino acids) components from the original cereal, with the addition of residual starch and yeast [5].

It is estimated that in the bioethanol production processes, the utilization of $100 \mathrm{~kg}$ of grain feedstock results in about $40 \mathrm{~L}$ of ethanol, $32 \mathrm{~kg}$ of DDGS and $32 \mathrm{~kg}$ of $\mathrm{CO}_{2}$; in this way, a huge amount of DDGS is made available each year [6]. Due to its high contents of protein, nutrients, vitamins, simple sugars and digestible fiber, DDGS is commonly sold and used as a valuable feed for livestock. However, as some types of DDGS, especially from barley, contain small amounts of mycotoxin, other disposal methods rather than animal feed might be needed. Moreover, in recent years, the increasing production of bioethanol as renewable liquid fuel in the transportation sector has led to an overflowing production of DDGS, further supporting the need to find alternative routes for its effective exploitation [7,8]. For instance, applications are proposed in the bio-composite sector $[9,10]$ and especially in bio-chemical [7,11] and thermo-chemical $[2,3,5,12-14]$ conversion.

The latter processes can be profitably applied to convert DDGS to renewable bioenergy, biofuels and biomaterials. However, the high content of protein-nitrogen and ashes (large 
quantities of $\mathrm{P}, \mathrm{K}, \mathrm{Na}$ and $\mathrm{Mg}$ ) limit the exploitation of feedstock for gasification and cocombustion with coal, due to potential excessive $\mathrm{NO}_{\mathrm{x}}$ emissions and problems of slagging, fouling, corrosion and loss of fluidization [2,3]. Instead, pyrolysis is a more versatile technology that may be able to effectively convert this protein- and lignin-rich biomass into energy-dense biofuels, namely bio-oil and biochar, with the potential concomitant production of value-added chemicals. Furthermore, in pyrolysis, nitrogen can be recycled in the form of ammonia from the liquid phase products or retained in the biochar, to obtain a potential alternative to fossil-based $\mathrm{N}$-containing fertilizers to compensate $\mathrm{N}$ lost during crop cultivation (closed N-loop). The lignin, a recalcitrant biopolymer for biochemical conversion, as a natural source of phenolics, can be pyrolytically decomposed and upgraded into fuels rich in aromatic hydrocarbons [7]. Therefore, the effective pyrolytic conversion of DDGS to second-generation biofuels and added-value products can certainly lead to significant economic benefits and waste reduction for bioethanol plants, within a biorefinery concept.

According to the considerations reported above, the knowledge of the characteristics and kinetics of DDGS pyrolysis is of significant interest since they are needed for plant design and optimization using comprehensive mathematical modeling [15-18]. However, the information currently available on the DDGS pyrolysis kinetics is relatively scarce $[3,12,19,20]$. The approach is based on simple global one-step models, characterized by low activation energies (for instance, Refs. $[12,19]$ ) or on parameters, specifically the activation energy, functions of the conversion degree (e.g., results from distributed activation energy or iso-conversional methods, such as Refs. $[3,20])$. This kinetics, although interesting and valuable, is either exceedingly simplified or not attractive for coupling with the description of transport phenomena to model practical systems. On the other hand, though a semi-global mechanism capable of capturing the different stages of the conversion process has been proposed [2] for the combustion of DDGS and the resulting char, given the influence of oxygen on the decomposition pathways [21-23], it cannot be applied under pyrolysis conditions. Hence, a semi-global mechanism for the pyrolysis (thermal devolatilization) of DDGS is not available in the literature.

In this study, thermogravimetric curves are measured in nitrogen for the thermal devolatilization of DDGS originated from barley grain. A comparison is proposed with beech wood and barley straw, taken as typical lignocellulosic feedstocks. The weight loss data for DDGS in nitrogen under different thermal conditions is used to formulate a multi-step kinetic model including the estimation of the kinetic constants. Finally, the influences of the air (versus nitrogen) on the devolatilization kinetics are also addressed by means of a comparison with results already available for the former [2].

\section{Materials}

The DDGS sample investigated in this study was the same examined in a previous study of this group [2]. It was produced in a plant in Spain converting barley seeds (Hordeum Vulgare) into ethanol with a dry-grind process. The sample was made available by the manufacturer in the shape of pellets (diameter $6 \mathrm{~mm}$, Figure 1). Before the experiments, it was subjected to milling and grinding, resulting in particle sizes below $80 \mu \mathrm{m}$, and drying (oven at $373 \mathrm{~K}$ for about $18 \mathrm{~h}$ ). The chemical and elemental compositions and the proximate analysis of DDGS, beech wood and barley straw samples were derived from previous literature $[2,3,12,24-28]$ and are listed in Table 1.

The total contribution of the three main biomass macro-components in the DDGS composition is only approximately $50 \mathrm{wt} \%$, with a protein content of approximately $38 \mathrm{wt} \%$. Thus, as anticipated, the content of the holocellulose components is lower than that typical of lignocellulosic biomass [28] (values of $19 \mathrm{wt} \% \mathrm{vs} .78$ and $54 \mathrm{wt} \%$ for beech wood and barley straw, respectively), while the content of lignin is higher (values of about $30 \mathrm{wt} \%$ vs. 20 and $17 \mathrm{wt} \%$ for beech wood and barley straw, respectively). The $\mathrm{C}$ and $\mathrm{H}$ contents of DDGS are comparable with those of wood and barley straw but the $\mathrm{N}$ and $\mathrm{S}$ contents are significantly higher (conversely, the $\mathrm{O}$ content is lower). The ash content $(7.1 \mathrm{wt} \%)$ is 
much higher than that of beech wood (approximately $0.4 \mathrm{wt} \%$ ) but comparable with that of barley straw $(9 \mathrm{wt} \%)$ (comparable contents of volatile matter (VM) and fixed carbon (FC)).

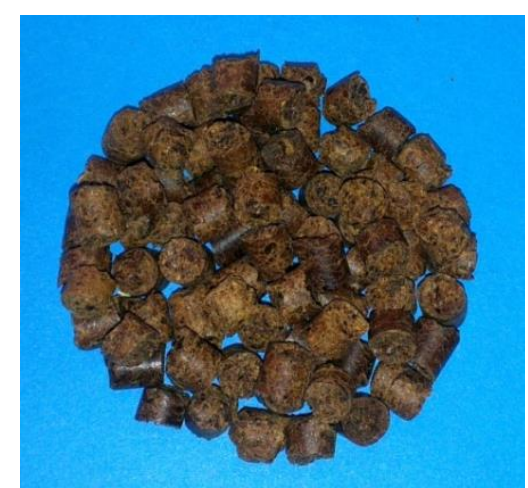

Figure 1. Snapshot of the DDGS sample as provided by the producer in the shape of pellets (properties listed in Table 1).

Table 1. Chemical and elemental compositions and proximate analysis of the DDGS, beech wood and barley straw samples.

\begin{tabular}{|c|c|c|c|c|}
\hline & & DDGS & Beech Wood & Barley Straw \\
\hline \multirow{6}{*}{$\begin{array}{l}\text { Chemical composition } \\
(\mathrm{wt} \%, \mathrm{db})\end{array}$} & & & & \\
\hline & cellulose & $15.0(12)$ & $45(25)$ & $33.2(24)$ \\
\hline & hemicellulose & $5.4(12)$ & $33(25)$ & $20.4(24)$ \\
\hline & lignin & $29.8(12)$ & $20(25)$ & $17.3(24)$ \\
\hline & extractives & - & $2(25)$ & $3.5(24)$ \\
\hline & protein + amino acid & $38.2(12)$ & - & $3.6(24)$ \\
\hline \multirow{6}{*}{$\begin{array}{l}\text { Elemental composition } \\
\qquad(w t \%, d b)\end{array}$} & & & & \\
\hline & $\mathrm{C}$ & $49.0(3)$ & $48.3(2)$ & $48(27)$ \\
\hline & $\mathrm{H}$ & $6.3(3)$ & $6.02(2)$ & $5.9(27)$ \\
\hline & $\mathrm{N}$ & $4.5(3)$ & $0.30(2)$ & $0.80(27)$ \\
\hline & $S$ & $0.4(3)$ & $<0.05(2)$ & $0.15(27)$ \\
\hline & $\mathrm{O}$ & $33.6(3)$ & $45.3(2)$ & $44.0(27)$ \\
\hline \multirow{4}{*}{$\begin{array}{l}\text { Proximate analysis } \\
\qquad(w t \%, d b)\end{array}$} & & & & \\
\hline & VM & $78.2(3)$ & $86.8(28)$ & $75.0(26)$ \\
\hline & FC & $14.7(3)$ & $13.1(28)$ & $15.9(26)$ \\
\hline & ASH & $7.1(3)$ & $0.14(28)$ & $9.1(26)$ \\
\hline
\end{tabular}

\section{Methods}

Thermogravimetric curves were measured using the commercial system Mettler $\mathrm{TGA} / 1$, with a pulverized sample mass of $4.5 \mathrm{mg}$, and heating rates of 5,10 and $20 \mathrm{~K} / \mathrm{min}$ up to a final temperature of $773 \mathrm{~K}$, under a nitrogen flow of $50 \mathrm{~mL} / \mathrm{min}$. Moreover, only for the case of a heating rate of $5 \mathrm{~K} / \mathrm{min}$, taking in mind that under oxidative conditions char combustion also takes place and to facilitate the comparison, for both air and nitrogen the final temperature was increased to $900 \mathrm{~K}$. The standard $70 \mu \mathrm{L}$ crucible was an alumina cylinder (wall thickness of approximately $0.45 \mathrm{~mm}$ ) with an internal diameter of $4.8 \mathrm{~mm}$ and a height of $4.5 \mathrm{~mm}$. Each thermogravimetric test was performed in triplicate, showing good repeatability.

\section{Results}

Results are first presented concerning the thermogravimetric behavior of the DDGS samples, including a comparison between thermal and oxidative devolatilization. Then, results of the kinetic analysis with the formulation of a multi-step mechanism and the estimation of the related kinetic constants are discussed. 


\subsection{Thermogravimetric Behavior}

Figure 2 reports the weight loss curves (mass fraction, TG, and time derivative of the mass fraction, DTG) for the DDGS sample as measured in nitrogen and air at a heating rate of $5 \mathrm{~K} / \mathrm{min}$ (in this case a final temperature of $950 \mathrm{~K}$ is applied). For a quantitative analysis of the thermogravimetric behavior, some characteristic temperatures, mass fractions and devolatilization rates can be defined [2] including the initial temperature $\left(\mathrm{T}_{\mathrm{i}}\right)$, corresponding to a mass fraction of 0.98 , the final degradation temperature $\left(\mathrm{T}_{\mathrm{f}}\right)$, corresponding to an attainment of a rate of volatile release equal to the $10 \%$ of the maximum rate, the temperatures, $\mathrm{T}_{\mathrm{pi}}(\mathrm{i}=1,2,3)$, of the three DTG peaks, with the corresponding devolatilization rates, $-(\mathrm{dY} / \mathrm{dt})_{\mathrm{pi}}$, and mass fractions, $\mathrm{Y}_{\mathrm{pi}}$, the char yield, $\mathrm{Y}_{773}$ (the solid mass fraction detected at $773 \mathrm{~K}$ ) and the full width of the temperature range where devolatilization occurs defined as $\mathrm{FW}=\mathrm{T}_{\mathrm{f}}-\mathrm{T}_{\mathrm{i}}$. These parameters for the curves of interest are listed in Table 2.

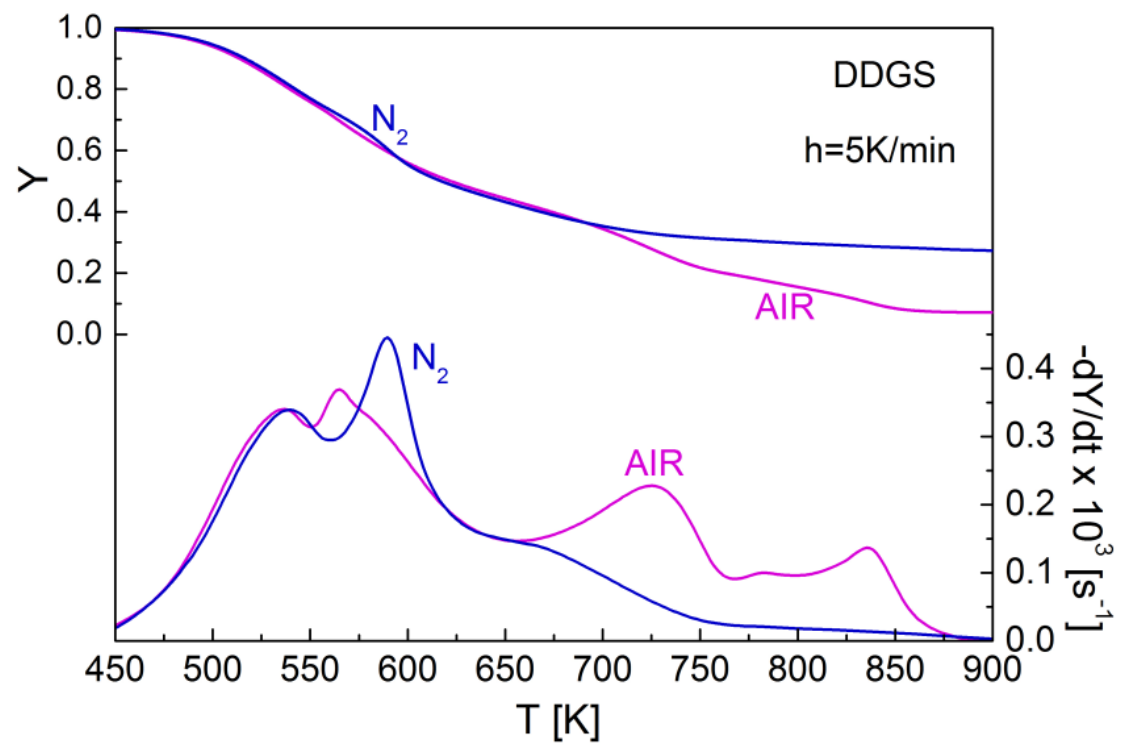

Figure 2. Mass fraction, $\mathrm{Y}$, and mass loss rate, $-\mathrm{dY} / \mathrm{dt}$, for the DDGS sample versus temperature as measured in nitrogen and in air at a heating rate of $5 \mathrm{~K} / \mathrm{min}$.

Table 2. Characteristic parameters of the thermogravimetric curves, for the DDGS sample at the different heating rates, $\mathrm{h}$ : initial degradation temperature, $\mathrm{T}_{\mathrm{i}}$, temperatures at the peaks, $\mathrm{T}_{\mathrm{pi}}$, and corresponding mass fractions, $\mathrm{Y}_{\mathrm{pi}}$, and rates of mass loss, $-(\mathrm{dY} / \mathrm{dt})_{\mathrm{pi}}$, full width, $\mathrm{FW}$, and solid residue at $773 \mathrm{~K}, \mathrm{Y}_{773}$. The data for beech wood and barley straw at $\mathrm{h}=5 \mathrm{~K} / \mathrm{min}$ are also reported for comparison.

\begin{tabular}{cccccc}
\hline Biomass & & DDGS & \multicolumn{2}{c}{ Wood } & Straw \\
$\mathbf{h}(\mathbf{K} / \mathbf{m i n})$ & $\mathbf{5}$ & $\mathbf{1 0}$ & $\mathbf{2 0}$ & $\mathbf{5}$ & $\mathbf{5}$ \\
\hline $\mathrm{T}_{\mathrm{i}}(\mathrm{K})$ & 464 & 470 & 475 & 501 & 481 \\
$\mathrm{~T}_{\mathrm{p} 1}(\mathrm{~K})$ & 538 & 544 & 550 & $560 \mathrm{sh}$ & - \\
$\mathrm{T}_{\mathrm{p} 2}(\mathrm{~K})$ & 589 & 596 & 601 & 613 & 581 \\
$\mathrm{~T}_{\mathrm{p} 3}(\mathrm{~K})$ & 664 & 673 & 681 & - & - \\
$\mathrm{T}_{\mathrm{f}}(\mathrm{K})$ & 735 & 755 & 750 & 639 & 656 \\
$\mathrm{FW}(\mathrm{K})$ & 271 & 285 & 285 & 129 & 166 \\
$-(\mathrm{dY} / \mathrm{dt})_{\mathrm{p} 1} \times 10^{3}\left(\mathrm{~s}^{-1}\right)$ & 0.34 & 0.71 & 1.46 & $0.44 \mathrm{sh}$ & - \\
$-(\mathrm{dY} / \mathrm{dt})_{\mathrm{p} 2} \times 10^{3}\left(\mathrm{~s}^{-1}\right)$ & 0.45 & 0.88 & 1.72 & 0.91 & 0.69 \\
$-(\mathrm{dY} / \mathrm{dt})_{\mathrm{p} 3} \times 10^{3}\left(\mathrm{~s}^{-1}\right)$ & 0.14 & 0.29 & 0.57 & - & - \\
$\mathrm{Y}_{\mathrm{p} 1}$ & 0.82 & 0.81 & 0.81 & $0.80 \mathrm{sh}$ & - \\
$\mathrm{Y}_{\mathrm{p} 2}$ & 0.61 & 0.60 & 0.60 & 0.41 & 0.63 \\
$\mathrm{Y}_{\mathrm{p} 3}$ & 0.41 & 0.40 & 0.40 & - & - \\
$\mathrm{Y}_{773}$ & 0.31 & 0.29 & 0.28 & 0.19 & 0.32 \\
\hline
\end{tabular}


The DDGS thermogravimetric curves in nitrogen show two main conversion zones with a boundary around $625 \mathrm{~K}$ and a corresponding mass fraction of 0.48 : a first one, where the large part of the volatile products is released, followed at higher temperature by the second one with slower devolatilization rates. The first zone of intense devolatilization concerns the release of about $75 \%$ of the total volatile matter. In agreement with previous findings [2,3], two well-evident peaks, at 538 and $590 \mathrm{~K}$, are identified for this first zone, with the second coincident with the maximum devolatilization rate of $0.45 \times 10^{-3} \mathrm{~s}^{-1}$ (value of $0.34 \times 10^{-3} \mathrm{~s}^{-1}$ for the first peak). In the second zone, the devolatilization continues with lower and slowly decaying rates. A third barely visible peak/shoulder is detected at about $664 \mathrm{~K}$ (peak rate of $0.14 \times 10^{-3} \mathrm{~s}^{-1}$ ). The main qualitative features of the weight loss curves are preserved as the heating rate is increased though, as already known, the reaction process tends to occur at successively higher temperatures (Table 2).

The DDGS curves obtained in nitrogen and air show significant similarities. In air, the second peak rate is anticipated at slightly lower temperatures $\left(\mathrm{T}_{\mathrm{p} 2}=565 \mathrm{~K}\right)$ and there is a more evident overlap with the first one, in consequence of the enhancement in the degradation process caused by the presence of oxygen, as already observed for lignocellulosic fuels [21]. After a local minimum, the main features of the second zone, in the presence of air consist of two well-defined peak rates at about 730 and $840 \mathrm{~K}$, testifying char oxidation [23].

Figure 3 compares the devolatilization behavior of DDGS with beech wood and barley straw which are two typical lignocellulosic biomasses (heating rate $5 \mathrm{~K} / \mathrm{min}$ ). The differences are remarkable from both a qualitative and a quantitative point of view. Firstly, the DDGS conversion occurs over a much wider temperature range (FW of $271 \mathrm{~K}$ for DDGS and of $129 \mathrm{~K}$ and $166 \mathrm{~K}$ for wood and straw, respectively) and consequently with slower average rates of mass loss. Moreover, the positions of the peaks/shoulders of the differential curves are different.

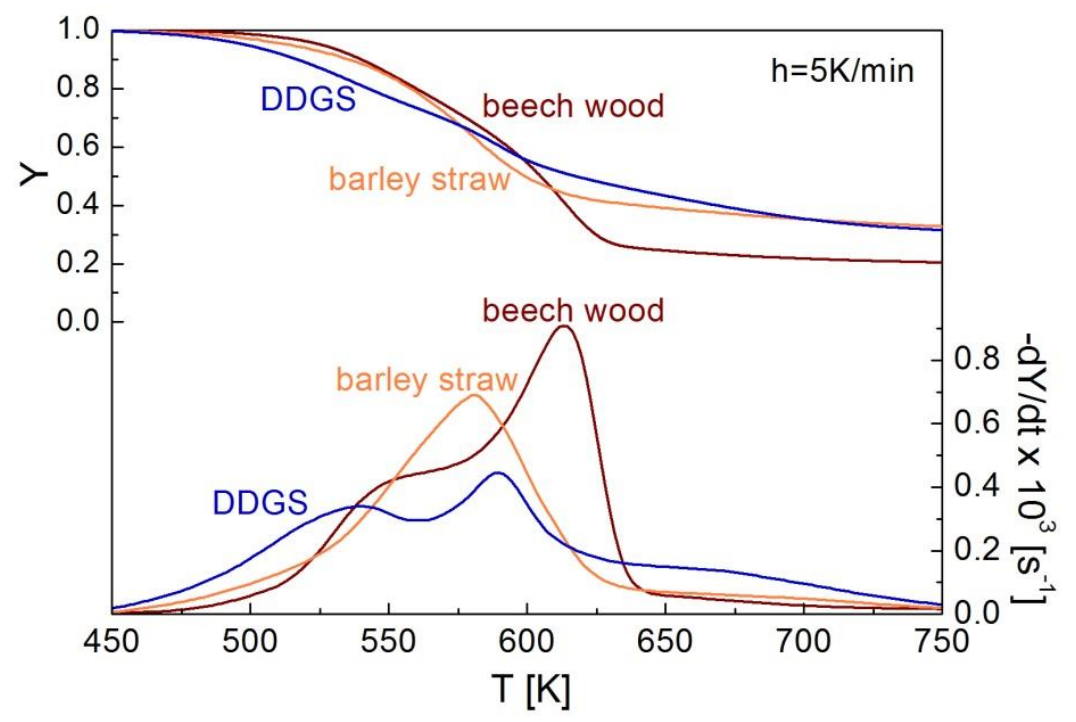

Figure 3. Mass fraction, $\mathrm{Y}$, and mass loss rate, $-\mathrm{dY} / \mathrm{dt}$, for DDGS, beech wood and barley straw measured in nitrogen versus temperature (heating rate $5 \mathrm{~K} / \mathrm{min}$ ).

Compared with beech wood, instead of the usual shoulder and absolute maximum rate, DDGS shows two consecutive lower peak rates which are also attained at lower temperatures. These findings can be attributed to the large amounts of ashes present in DDGS which displace thermal degradation at lower temperatures and favor charring reactions [29-31]. As also observed for other non-conventional lignocellulosic biomasses [32], the second DDGS peak rate is very wide. Indeed, it is not associated with the sole decomposition of cellulose, such as in the case of beech wood. The first zone of intense devolatilization of DDGS and straw is approximately localized over the same temperature range and the char yield (Y773) is also comparable. The large ash content and peculiar 
chemical composition of DDGS may justify the strong overlap between the various conversion zones. Moreover, the DDGS curves always show conversion rates higher than those of wood and straw at very low (below $530 \mathrm{~K}$ ) and high (above $640 \mathrm{~K}$ ) temperatures.

The differences between the conversion behavior of DDGS and the two lignocellulosic biomasses are attributable to the different chemical natures and contents of macrocomponents and inorganics. Indeed, associated with the lower amount of holocellulose degrading with significant rates over a relatively narrow temperature range, the content of proteins and other components is high for DDGS. These are characterized by slower decomposition rates occurring over a wider temperature range. In fact, proteins are reported [33] to mainly degrade at temperatures as low as $500 \mathrm{~K}$ and as high as $708 \mathrm{~K}$, depending on their specific nature. Moreover, the weight losses between 473 and $523 \mathrm{~K}$ can be attributed to the evaporation/decomposition of some oils, such as glycerin, palmitic acid and linoleic acid [2].

\subsection{Kinetic Modelling}

Lumped reaction mechanisms are widely applied to perform kinetic computations for the thermal and oxidative degradation of lignocellulosic materials [2,21,32,34-37]. Briefly, it is assumed that volatiles are released according to a set of parallel reactions for the release of lumped classes of volatile products from the macro-components of the lignocellulosic biomass, then the overall rate is obtained from the sum of the component rates. Pseudo-components (i.e., fractions of chemical components that exhibit similar reactivity) are introduced as modeling and interpretation of the measurements do not permit anyway a complete separation in the actual contribution of the chemical components [32,38]. In the case of DDGS devolatilization, the kinetic analysis is complicated due to the significant number of chemical components and the large share of alkali metals in the inorganic fraction, which enhance the overlap among the degradation rates of the various components. As a consequence, the identification of the contribution from the main components, which is partly possible in the case of wood [36] and of other lignocellulosic residues with a standard composition [37], is more difficult. Therefore, only a lumped model can be formulated where each reaction step considers the simultaneous contribution of several components. Based on the analysis of the thermogravimetric characteristics reported above, it is found that the devolatilization of DDGS can be well described by a set of five pseudo-components (parallel global reactions):

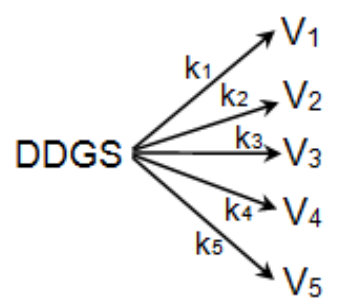

with the formation of the lumped volatile products $V_{i}(i=1, \ldots, 5)$.

The reaction rates present the usual Arrhenius dependence on temperature $\left(A_{i}\right.$ are the pre-exponential factors and $\mathrm{E}_{\mathrm{i}}$ the activation energies) and a linear dependence on the evolved volatile mass fraction. The sample temperature, $\mathrm{T}$, is a known function of time so that the mathematical model consists of five ordinary equations for the mass fractions, $\mathrm{Y}_{\mathrm{i}}$, of volatiles generated from each pseudo-component $i$, whose initial values, $v_{i}$, are indicated as stoichiometric coefficients:

$$
\frac{d Y_{i}}{d t}=-A_{i} \exp \left(-\frac{E_{i}}{R T}\right) Y_{i}, Y_{i}(0)=v_{i}, i=1, \ldots, 5
$$

The kinetic parameters to be estimated are $A_{i}, E_{i}, n_{i}, v_{i}$. These are numerically estimated considering simultaneously both TG and DTG data for the various heating rates, 
following the method already described [36] based on the application of a direct method for the minimization of the objective function. The estimated parameters are invariant with the heating rate, except for the stoichiometric coefficients which are generally permitted to show small variations owing to the dependence of the total volatile yields on the heating rate. However, for the DDGS, it has been found that constant (average) values can be used without loss of accuracy in the predictions. Finally, deviations between measurements and model predictions, $\operatorname{dev}_{\mathrm{TG}}$ and $\operatorname{dev}_{\mathrm{DTG}}$, are defined as in [39].

The estimated values of the kinetic parameters and the deviations between predictions and measurements are reported in Table 3. Examples of the component dynamics are shown in Figure 4 for a heating rate of $5 \mathrm{~K} / \mathrm{min}$. The agreement between predictions and measurements is good as indicated by the small values of the deviations (Table 3) and the comparison in terms of global rates of mass loss made in Figure 5 for the various heating rates.

Table 3. Estimated kinetic parameters (activation energy, $E_{i}$, and pre-exponential factor, $A_{i}$, and stoichiometric coefficients, $v_{\mathrm{i}}$ ) for the thermal devolatilization of DDGS and corresponding deviations between measured and simulated integral ( $\left.\operatorname{dev}_{\mathrm{TG}}\right)$ and differential $\left(\operatorname{dev}_{\mathrm{DTG}}\right)$ curves.

\begin{tabular}{cc}
\hline Parameters & \\
\hline $\mathrm{E}_{1}(\mathrm{~kJ} / \mathrm{mol})$ & 88.7 \\
$\mathrm{~A}_{1}\left(\mathrm{~s}^{-1}\right)$ & $1.36 \times 10^{7}$ \\
$v_{1}$ & 0.05 \\
$\mathrm{E}_{2}(\mathrm{~kJ} / \mathrm{mol})$ & 120.5 \\
$\mathrm{~A}_{2}\left(\mathrm{~s}^{-1}\right)$ & $3.68 \times 10^{9}$ \\
$v_{2}$ & 0.19 \\
$\mathrm{E}_{3}(\mathrm{~kJ} / \mathrm{mol})$ & 158.0 \\
$\mathrm{~A}_{3}\left(\mathrm{~s}^{-1}\right)$ & $7.34 \times 10^{11}$ \\
$v_{3}$ & 0.23 \\
$\mathrm{E}_{4}(\mathrm{~kJ} / \mathrm{mol})$ & 102.2 \\
$\mathrm{~A}_{4}\left(\mathrm{~s}^{-1}\right)$ & $8.30 \times 10^{5}$ \\
$v_{4}$ & 0.15 \\
$\mathrm{E}_{5}(\mathrm{~kJ} / \mathrm{mol})$ & 112.9 \\
$\mathrm{~A}_{5}\left(\mathrm{~s}^{-1}\right)$ & 8.1 \\
$v_{5}$ & 0.5 \\
$\operatorname{dev}_{\mathrm{TG}}(\%)$ & 0.092 \\
$\operatorname{dev}_{\mathrm{DTG}}(\%)$ & 0.49 \\
\hline
\end{tabular}

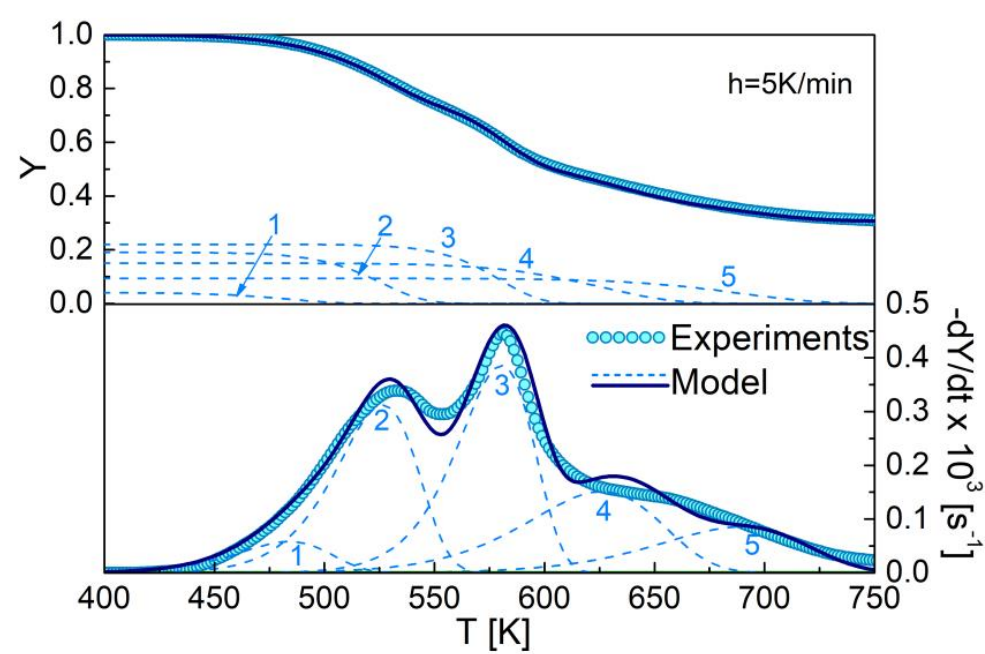

Figure 4. redicted (kinetic parameters listed in Table 3) (solid lines) and measured (symbols) mass fraction, $\mathrm{Y}$, and mass loss rate, $-\mathrm{dY} / \mathrm{dt}$, for DDGS thermal devolatilization, and predicted rates of volatile release (dashed lines) from the model components $\mathrm{n}$. $1-5$, versus temperature (heating rate $5 \mathrm{~K} / \mathrm{min}$ ). 


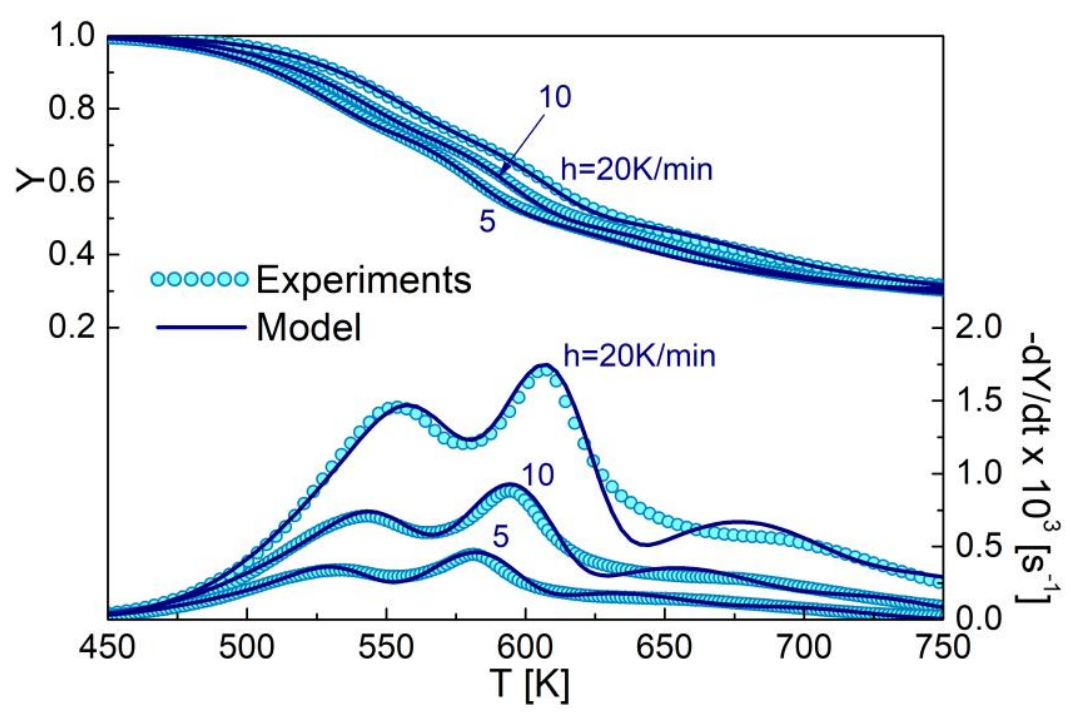

Figure 5. Comparison between predictions (kinetic parameters listed in Table 3) (solid lines) and measurements (symbols) of mass fraction, $\mathrm{Y}$, and mass loss rate, $-\mathrm{dY} / \mathrm{dt}$, for DDGS versus temperature at various heating rates, $\mathrm{h}$, for thermal devolatilization.

Figure 4 shows that, as expected, a significant overlap can be observed between the model components which also exhibit significant rates over a wide temperature interval, as they should account for the simultaneous degradation of numerous components (proteins, starch, extractives, in addition to cellulose, hemicelluloses and lignin) and the catalytic effect of alkali compounds. As a consequence, the estimated activation energies $(89,120,158,102$ and $113 \mathrm{~kJ} / \mathrm{mol}$ ) are significantly lower than those typically reported for the devolatilization of the pseudo-components hemicellulose, cellulose and lignin for lignocellulosic materials (for instance, values of 130, 191 and $188 \mathrm{~kJ} / \mathrm{mol}$ for beech wood [36]).

The analysis of the process dynamics reveals that similar to the case of oxidative degradation [2], reaction steps 2 and 3 are quantitatively the most important, comprising about 27 and $32 \mathrm{wt} \%$ of the total volatile released, over temperature ranges of approximately $480-560 \mathrm{~K}$ and $540-610 \mathrm{~K}$, respectively. Reaction step 4 accounts for about $21 \mathrm{wt} \%$ of the total mass loss and its activity is exerted over a very wide temperature range (about $130 \mathrm{~K})$. Finally, reaction steps 1 and 5 cause the further release of about 7 and $13 \mathrm{wt} \%$ mass, respectively.

If compared with the activation energies reported for the devolatilization stage of DDGS oxidative devolatilization [2], larger values have been estimated in this study for the two major reaction steps (values of 120.5 and $158 \mathrm{~kJ} / \mathrm{mol} \mathrm{vs.} 107$ and $108 \mathrm{~kJ} / \mathrm{mol}$ in nitrogen and air, respectively). This finding can be attributed to the enhanced overlap between the degradation process of the two components caused by the presence of oxygen. This effect is especially marked for the model component corresponding to the absolute DTG peak (the third and the second component for inert and oxidative atmosphere, respectively), whose dynamics are likely to be partially dominated by the cellulose. It should also be noticed that the values reported in [2] for the oxidative degradation of DDGS refer to a non-linear model so that the comparison is not truly rigorous.

\section{Conclusions}

The thermal devolatilization behavior of DDGS is investigated using a thermogravimetric system. As expected, the process characteristics are highly different from those observed for standard lignocellulosic biomass, from both a qualitative and a quantitative point of view. Conversion of DDGS takes place over a much wider temperature range (about $450-750 \mathrm{~K}$ ) with slower rates. In particular, the positions of the main devolatilization events (DTG peaks and shoulders) do not coincide with those exhibited by wood. The kinetic analysis, carried out using experimental data produced at various heating rates, 
indicates that the process is well described by five global reactions with activation energies that are lower than those typically estimated for lignocellulosic fuels. It is plausible that the interaction between the non-lignocellulosic components (proteins, starch and extractives) and the lignocellulosic components (cellulose, hemicellulose and lignin) during DDGS pyrolysis and the ashes present are responsible for such behavior. Finally, the estimated activation energies are, on average, higher than those previously estimated for oxidative conditions. The kinetic mechanism developed in this study can be easily combined with the description of relevant physical phenomena to model chemical reactors for DDGS pyrolysis, aimed at process design and development. However, other aspects of DDGS pyrolysis kinetics still require further attention in future research. The influences of the DDGS origin and production methodologies/conditions on the reaction mechanism and kinetic parameters are unknown. The role of indigenous or added catalysts, in the reaction paths and product yields and properties, also needs to be ascertained. Finally, more detailed reaction mechanisms should be developed which can describe the formation of specific volatile compounds (versus the lumped classes of volatile products considered in this study).

Author Contributions: Conceptualization, C.B. and C.D.B.; methodology, C.B.; investigation, C.B. and C.D.B.; writing—original draft preparation, C.B.; writing-review and editing, C.B. and C.D.B. All authors have read and agreed to the published version of the manuscript.

Funding: This research received no external funding.

Conflicts of Interest: The authors declare no conflict of interest.

\section{References}

1. Cheng, F.; Bayat, H.; Jena, U.; Brewer, C.E. Impact of feedstock composition on pyrolysis of low-cost, protein- and lignin-rich biomass: A review. J. Anal. Appl. Pyrolysis 2020, 147, 104780. [CrossRef]

2. Branca, C.; Di Blasi, C. Thermogravimetric analysis of the combustion of dry distiller's grains with solubles (DDGS) and pyrolysis char under kinetic control. Fuel Proc. Technol. 2015, 129, 67-74. [CrossRef]

3. Giuntoli, J.; de Jong, W.; Arvelakis, S.; Spliethoff, H.; Verkooijen, A.H.M. Quantitative and kinetic TG-FTIR study of biomass residue pyrolysis: Dry Distiller's Grains with Solubles (DDGS) and chicken manure. J. Anal. Appl. Pyrolysis 2009, 85, 301-312. [CrossRef]

4. Veljković, V.B.; Biberdžić, M.O.; Banković-Ilić, I.B.; Djalović, I.G.; Tasić, M.B.; Nježić, Z.B.; Stamenković, O.S. Biodiesel production from corn oil: A review. Renew. Sustain. Energy Rev. 2018, 91, 531-548. [CrossRef]

5. Qi, W.; Yang, W.; Xu, Q.; Xu, Z.; Wang, Q.; Liang, C.; Liu, S.; Ling, C.; Wang, Z.; Yuan, Z. Comprehensive research on the influence of nonlignocellulosic components on the pyrolysis behavior of Chinese distiller's grain. ACS Sustain. Chem. Eng. 2020, 8, 3103-3113. [CrossRef]

6. Chatzifragkoua, A.; Kosik, O.; Prabhakumari, P.C.; Lovegrove, A.; Frazier, R.A.; Shewry, P.R.; Charalampopoulos, D. Biorefinery strategies for upgrading Distillers' Dried Grains with Solubles (DDGS). Process Biochem. 2015, 50, 2194-2207. [CrossRef]

7. Cheng, F.; Brewer, C.E. Producing jet fuel from biomass lignin: Potential pathways to alkyl-benzenes and cycloalkanes. Renew. Sustain. Energy Rev. 2017, 72, 673-722. [CrossRef]

8. Chrastina, J.; Staroňová, L.; Vitázek, I.; Pšenka, M. Analysis of residual biomass of liquid biofuels using gravimetric method and combustion heat. Res. Agric. Eng. 2015, 61, S21-S25. [CrossRef]

9. Liaw, J.D.; Bajwa, D.S.; Shojaeiarani, J.; Bajwa, S.G. Corn distiller's dried grains with solubles (DDGS)—A value added functional material for wood composites. Ind. Crops Prod. 2019, 139, 111525. [CrossRef]

10. Zarrinbakhsh, N.; Mohanty, A.K.; Misra, M. Fundamental studies on water-washing of the corn ethanol coproduct (DDGS) and its characterization for biocomposite applications. Biomass Bioenergy 2013, 55, 251-259. [CrossRef]

11. Huda, M.S.; Nahar, N.; Monono, E.; Regmi, S. Oil Recovery from fractionated Dried Distillers Grains with Solubles (DDGS) using enzymes. Processes 2021, 9, 1507. [CrossRef]

12. Gudka, B.; Darvell, L.I.; Jones, J.M.; Williams, A.; Kilgallon, P.J.; Simms, N.J.; Laryea-Goldsmith, R. Fuel characteristics of wheat-based Dried Distillers Grains and Solubles (DDGS) for thermal conversion in power plants. Fuel Process. Technol. 2012, 94, 123-130. [CrossRef]

13. Lv, J.; Ao, X.; Li, Q.; Cao, Y.; Chen, Q.; Xie, Y. Steam co-gasification of different ratios of spirit-based distillers' grains and anthracite coal to produce hydrogen-rich gas. Bioresour. Technol. 2019, 283, 59-66. [CrossRef]

14. Zhang, B.; Zhong, Z.; Li, T.; Xue, Z.; Wang, X.; Ruan, R. Biofuel production from distillers dried grains with solubles (DDGS) co-fed with waste agricultural plastic mulching films via microwave-assisted catalytic fast pyrolysis using microwave absorbent and hierarchical ZSM-5/MCM-41 catalyst. J. Anal. Appl. Pyrolysis 2018, 130, 1-7. [CrossRef]

15. Di Blasi, C. The state of the art of transport models for charring solid degradation. Polym. Int. 2000, 49, 1133-1146. [CrossRef] 
16. Di Blasi, C.; Branca, C. Modeling a stratified downdraft wood gasifier with primary and secondary air entry. Fuel 2013, 104, 847-860. [CrossRef]

17. Xiong, Q.; Yang, Y.; Xu, F.; Pan, Y.; Zhang, J.; Hong, K.; Lorenzini, G.; Wang, S. Overview of computational fluid dynamics simulation of reactor-scale biomass pyrolysis. ACS Sustain. Chem. Eng. 2017, 5, 2783-2798. [CrossRef]

18. Fatehi, H.; Weng, W.; Li, Z.; Bai, X.S.; Aldén, M. Recent development in numerical simulations and experimental studies of biomass thermochemical conversion. Energy Fuels 2021, 35, 6940-6963. [CrossRef]

19. Xu, B.; Fang, B.; Sun, G. Kinetic study of decomposition of wheat distiller grains and steam gasification of the corresponding pyrolysis char. J. Therm. Anal. Calorim. 2011, 108, 109-117. [CrossRef]

20. Zhang, Y.; Huang, G.; Yu, S.; Gu, X.; Cai, J.; Zhang, X. Physicochemical characterization and pyrolysis kinetic analysis of Moutai-flavored dried distiller's grains towards its thermochemical conversion for potential applications. J. Anal. Appl. Pyrolysis 2021, 155, 105046. [CrossRef]

21. Brostrom, M.; Nordin, A.; Pommer, L.; Branca, C.; Di Blasi, C. Influence of torrefaction on the devolatilization and oxidation kinetics of wood. J. Anal. Appl. Pyrolysis 2012, 96, 100-109. [CrossRef]

22. Moreno, A.I.; Font, R.; Conesa, J.A. Combustion of furniture wood waste and solid wood: Kinetic study and evolution of pollutants. Fuel 2017, 192, 169-177. [CrossRef]

23. Branca, C.; Di Blasi, C. Burning dynamics of straw chars under the conditions of thermal analysis. Energy Fuels 2021, 35, 12187-12199. [CrossRef]

24. Adapaa, P.; Tabila, L.; Schoenau, G. Compaction characteristics of barley, canola, oat and wheat straw. Biosyst. Eng. 2009, 104, 335-344. [CrossRef]

25. Di Blasi, C.; Branca, C.; Masotta, F.; De Biase, E. Experimental analysis of reaction heat effects during beech wood pyrolysis. Energy Fuels 2013, 27, 2665-2674. [CrossRef]

26. Branca, C.; Di Blasi, C.; Galgano, A. Pyrolytic conversion of wastes from cereal, protein and oil-protein crops. J. Anal. Appl. Pyrolysis 2017, 127, 426-435. [CrossRef]

27. Bakker, R.R.; Elbersen, H.W.; Poppens, R.P.; Lesschen, J.P. Rice Straw and Wheat Straw. Potential Feedstocks for the Biobased Economy; NL Agency: The Ague, The Netherlands, 2013.

28. Di Blasi, C.; Galgano, A.; Branca, C. Exothermic events of nut shell and fruit stone pyrolysis. ACS Sustain. Chem. Eng. 2019, 7 , 9035-9049. [CrossRef]

29. Di Blasi, C.; Galgano, A.; Branca, C. Effects of potassium hydroxide impregnation on wood pyrolysis. Energy Fuels 2009, 23, 1045-1054. [CrossRef]

30. Di Blasi, C.; Branca, C.; Galgano, A. Influences of potassium hydroxide on the rate and thermicity of wood pyrolysis reactions. Energy Fuels 2017, 1, 6154-6162. [CrossRef]

31. Di Blasi, C.; Branca, C.; Galgano, A. Role of the potassium chemical state in the global exothermicity of wood packed-bed pyrolysis. Ind. Eng. Chem. Res. 2018, 57, 11561-11571. [CrossRef]

32. Branca, C.; Di Blasi, C. A lumped kinetic model for banana peel combustion. Thermochim. Acta 2015, 614, 68-75. [CrossRef]

33. Giuntoli, J. Characterization of 2nd Generation Biomass Under Thermal Conversion and the Fate of Nitrogen. Ph.D. Thesis, Delft University of Technology, Delft, The Netherlands, 2010.

34. Branca, C.; Di Blasi, C. Global intrinsic kinetics of wood oxidation. Fuel 2004, 83, 81-87. [CrossRef]

35. Branca, C.; Di Blasi, C. A unified mechanism of the combustion reactions of lignocellulosic fuels. Thermochim. Acta 2013, 565, 58-64. [CrossRef]

36. Branca, C.; Di Blasi, C. A summative model for the pyrolysis reaction heats of beech wood. Thermochim. Acta 2016, 638, 10-16. [CrossRef]

37. Branca, C.; Di Blasi, C. Thermal degradation behavior and kinetics of industrial hemp stalks and shives. Thermochim. Acta 2021, 697, 178878. [CrossRef]

38. Varhegyi, G. Aims and methods in non-isothermal reaction kinetics. J. Anal. Appl. Pyrolysis 2007, 79, 278-288. [CrossRef]

39. Branca, C.; Di Blasi, C.; Horacek, H. Analysis of the combustion kinetics and the thermal behavior of an intumescent system. Ind. Eng. Chem. Res. 2002, 41, 2104-2114. [CrossRef] 